九州大学学術情報リポジトリ

Kyushu University Institutional Repository

\title{
Green Disclosure Practices in India : A Study of Select Companies
}

Bhasin, Niti

Department of Commerce, delhi School of Economics, University of Delhi : Associate Professor

Kar, Rabi Narayan

Shyam Lal College, University of Delhi : Principal

Arora, Neha

Department of Commerce, Delhi School of Economics, University of Delhi : Research Scholar

https://doi.org/10.5109/1544075

出版情報: Evergreen. 2 (2)，pp.5-13，2015-09. Green Asia Education Center バージョン：

権利関係 : 


\title{
Green Disclosure Practices in India: A Study of Select Companies
}

\author{
Niti Bhasin ${ }^{1 *}$, Rabi Narayan $\mathrm{Kar}^{2}$, Neha Arora ${ }^{3}$ \\ ${ }^{1}$ Associate Professor, Department of Commerce, Delhi School of Economics, University of Delhi, India \\ ${ }^{2}$ Principal, Shyam Lal College, University of Delhi, India \\ ${ }^{3}$ Research Scholar, Department of Commerce, Delhi School of Economics, University of Delhi
}

*Author to whom correspondence should be addressed, E-mail: nitisurydse@gmail.com

(Received April 2, 2015; accepted August 25, 2015).

\begin{abstract}
Climate change is a global threat with catastrophic consequences for the entire ecosystem. Greenhouse gas emissions, the main reason behind climate change mainly stem from industrialisation. While economic development without industrialisation is not feasible, it leads to environmental degradation that affects economies in the long-run. Thus the emphasis now is on a stable and sustainable growth path whereby companies integrate sustainability in the process of development. In this context, companies have started providing information about their environmental performance and policies to various stakeholders. The present paper attempts to study the extent of environmental reporting by Indian companies. A sample of 30 Indian companies was taken and their annual reports were examined to gather information about the initiatives taken by these companies towards making India a low carbon economy. Content analysis was used to convert qualitative information in annual reports into quantitative information and an environmental disclosure index was calculated on the basis of themes identified for environmental information. Our results show that companies in the automobile and IT sector have the highest environmental score while companies in banking sector had low scores.
\end{abstract}

Keywords: Environmental disclosures, BSE listed companies, content analysis.

\section{Introduction}

The rapid industrialisation of many developing and emerging market economies has resulted in high levels of pollution that are adversely affecting the quality of life. This has resulted in rising concerns about environmental issues such as climate change and global warming, which are now seen as an important part of overall corporate strategy. Historically, companies believed that abiding by environmental regulations will be an expensive process and thus will have an adverse impact on corporate profits. However, extant literature in the area has shown that companies which are perceived to more environmentally aware are also financially more successful. Singh \& Sahay (2004), Goldar \& Gupta (2003) and Bammi (2013) have empirically confirmed that companies which are sensitive towards the environment experience a positive impact on their financial performance. As consumers are becoming more aware and concerned about the social and environmental impact of their lifestyle choices, the demand for environmental-friendly products has also gone up.

In the light of the above, companies are now moving towards adopting a sustainable approach in their operations that will ensure that resources are utilized in a manner that meets the expectations of the stakeholders and the society. More companies are now incorporating sustainability as an important corporate goal so as to maintain a balance between financial performance and environmental performance. They are developing environment-friendly products and services and adopting practices such as energy, water and waste management to succeed in the market place. The inherent belief while undertaking these measures is that they will improve the company's image as an 'environmentally conscious' corporate and hence their products and services will be more desired by the customers than their counterparts. To achieve this objective, companies should provide information about their environmental performance and policies to various stakeholders. The incorporation of environmental issues into the corporate annual report of a company is known as environmental reporting. Environmental reporting includes voluntary and involuntary disclosure of the environment related activities of a company. With the increasing competition from the rest of the world due to globalization, Indian companies have been compelled to adopt international norms of transparency, accountability and good 
governance. It is imperative for companies to disclose non-financial information apart from the standard financial information to increase the confidence of the various stakeholders of the company. Non-financial information such as environmental performance, social performance speaks volume about the business strategies of the company in the long term. The present study attempts to study the environmental disclosure practices of Indian companies and measure their environmental performance post SEBI regulation (inclusion of Business Responsibility Reports as part of Annual reports for top 100 listed companies). The remainder of this study proceeds as follows: Section 2 outlines the theoretical construct and review of literature; Section 3 discusses the Environmental Reporting in India; Section 4 provides the Data and Research Methodology; Section 5 discusses the results and analysis; Section 6 summarizes the study's implications and conclusions.

\section{Theoretical Construct of the Study}

In recent times, environmental reporting has emerged as an important dimension of reporting practices because stakeholders have started demanding disclosure of company's environmental information in view of the potential costs and liabilities associated with environmental issues. Companies should, therefore, consider using environmental annual reports to communicate with their stakeholders and foster a long term relationship between the shareholders (Mastrandonas \& Strife, 1992). In view of the growing importance of environmental reporting, we examine the extent of environmental disclosure by Indian companies by considering the 30 companies listed on the BSE Sensex of the Bombay Stock Exchange. In the present study, the Environmental disclosure practices of top 30 Indian companies was studied with the help of the identified 12 Environmental themes categorized under the sub-headings namely compliance with standards and procedures; efforts at resource conservation; and pollution abatement measures. These themes provided insights about the energy-efficiency and sustainable practices undertaken by Indian companies to reduce their carbon footprint and become green. The objectives of the study are as follows:

- To study the various regulations and laws for disclosure of environmental practices for Indian companies.

- To examine the nature and extent of environmental disclosure practices of Indian companies.

- To examine if the extent of environmental disclosure differs according to the type of industry.

\subsection{Review of Literature}

Environmental reporting by companies was first initiated in the developed countries namely US and UK. A number of studies for developed countries analyse the annual reports of companies to examine the extent, volume and type of environmental disclosure [Harte \& Owen (1991); Hughes et al. (2001); Ahmed \& Suleiman (2004); and Campbell (2004)]. Harte and Owen (1991) analyse the annual reports of 30 British companies in the year 1990 on two aspects, namely the form of reporting (financial and non-financial disclosure) and the statement of objectives. The findings show that environmental reporting by companies is done at a general level with little specific disclosure details. Another study on $10 \mathrm{UK}$ based companies in five sectors was conducted by Campbell (2004) to record the volume of voluntary environmental disclosure. He found an increase in environmental disclosure over the period of study. Harte \& Owen (2001) examine the environmental disclosure made by 51 US manufacturing firms using content analysis. The results indicate that there are differences in the extent to which different groups of environmental performers (rated good, bad or poor) disclose environmental information. A study on amount and nature of voluntary environmental disclosure in the annual reports for Malaysian companies by Ahmed and Suleiman (2004) reveals that the extent of disclosure was very low.

Another aspect of environmental reporting in literature is the debate on whether there is a link between environmental performance, economic performance and environmental disclosure of companies. Patten (2002) examines the relationship between environmental performance and environmental disclosure for US companies, by taking a sample of 131 US companies. Using content analysis, the annual reports were studied for measuring environmental disclosure of companies and environmental performance as based on data provided by the Environmental Protection Agency's 1988 Toxics Release Inventory. The results indicate that the disclosure for less environmentally sensitive companies is affected more by TRI data release as compared to environmentally sensitive companies. Tuwaijri et al (2004) studies the relationship among environmental disclosure, environmental performance and economic performance. The results show that good environmental performance is associated with good economic performance and also with quantifiable environmental disclosures of firms.

Studies on environmental reporting by Indian companies include those by Chatterjee \& Zaman (2008), Malavizhi \& Yadav (2008), Arora \& Kapoor (2012), Kundra (2013) and Goyal (2014). Chatterjee \& Zaman (2008) study 45 Indian companies to investigate their state of environmental reporting and find that companies provide more information on their company websites as compared to their annual reports. Malarvizhi and Yadav (2008) examine the corporate environmental reporting of top 24 Indian companies through the information given in company's annual report and find that Indian companies follow diverse reporting practices on the internet such as independent environmental reporting, 
Table 1: A Summary of studies on Environmental Disclosure Practices

\begin{tabular}{|c|c|c|c|c|}
\hline S.No. & Year & Author(s) & Objectives & Findings \\
\hline 1 & \multicolumn{4}{|c|}{ Environmental reporting in developed countries } \\
\hline 1.1 & 1991 & $\begin{array}{l}\text { Harte } \quad \& \\
\text { Owen }\end{array}$ & $\begin{array}{l}\text { To analyse the annual reports of } 30 \text { British } \\
\text { companies in the year } 1990 .\end{array}$ & $\begin{array}{l}\text { The results show that environmental reporting by } \\
\text { companies is done at a general level with little } \\
\text { specific disclosure details. }\end{array}$ \\
\hline 1.2 & 2001 & $\begin{array}{l}\text { Hughes et } \\
\text { al }\end{array}$ & $\begin{array}{l}\text { To study the environmental disclosures made } \\
\text { by } 51 \text { US manufacturing firms for } 1991 \text { and } \\
1993 \text {. }\end{array}$ & $\begin{array}{l}\text { The results indicate that there are differences in the } \\
\text { extent to which different groups of environmental } \\
\text { performers disclose environmental information. }\end{array}$ \\
\hline 1.3 & 2004 & Campbell & $\begin{array}{l}\text { To analyse the annual reports of } 10 \mathrm{UK} \text { based } \\
\text { companies in five sectors between } 1974 \text { and } \\
2000 \text { to record the volume of voluntary } \\
\text { environmental disclosure by companies. }\end{array}$ & $\begin{array}{l}\text { An increase in environmental disclosure over the } \\
\text { period with a marked upturn in the late } 1980 \text { 's. }\end{array}$ \\
\hline 1.4 & 2004 & $\begin{array}{l}\text { Ahmed \& } \\
\text { Sulieman }\end{array}$ & $\begin{array}{l}\text { To study the amount and nature of voluntary } \\
\text { environmental disclosures in annual reports } \\
\text { (year 2000) by Malaysian companies } \\
\text { belonging to construction and industrial } \\
\text { products industries. }\end{array}$ & $\begin{array}{l}\text { Their study concluded that the extent of } \\
\text { environmental disclosure was very low scattered all } \\
\text { over the report. }\end{array}$ \\
\hline 2 & \multicolumn{4}{|c|}{ Relationship between environmental performance, Environmental Disclosure and financial performance } \\
\hline 2.1 & 2002 & Patten & $\begin{array}{l}\text { To examine the relationship between } \\
\text { environmental } \\
\text { environmental disclosure for US companies. }\end{array}$ & $\begin{array}{l}\text { The results indicate that the disclosure for less } \\
\text { environmentally sensitive companies is affected } \\
\text { more by TRI data release than from } \\
\text { environmentally sensitive companies. }\end{array}$ \\
\hline 2.2 & 2004 & $\begin{array}{l}\text { Tuwaijri } \\
\text { et al }\end{array}$ & $\begin{array}{l}\text { To study the relationship among } \\
\text { environmental disclosure, environmental } \\
\text { performance and economic performance. }\end{array}$ & $\begin{array}{l}\text { The results show that good environmental } \\
\text { performance is associated with good economic } \\
\text { performance and also with quantifiable } \\
\text { environmental disclosures of firms. }\end{array}$ \\
\hline 3 & \multicolumn{4}{|c|}{ Environmental reporting by Indian Companies } \\
\hline 3.1 & 2008 & $\begin{array}{l}\text { Chatterjee } \\
\text { \& Zaman }\end{array}$ & $\begin{array}{l}\text { To look into state of Environmental } \\
\text { Reporting by Indian companies on their web } \\
\text { sites and annual reports. }\end{array}$ & $\begin{array}{l}\text { Companies provided more information on their } \\
\text { websites as compared to their annual reports. }\end{array}$ \\
\hline 3.2 & 2008 & $\begin{array}{l}\text { Malarvizvi } \\
\text { \& Yadav }\end{array}$ & $\begin{array}{l}\text { To apprehend the corporate environmental } \\
\text { reporting of top } 24 \text { Indian companies through } \\
\text { the information given on company's annual } \\
\text { report. }\end{array}$ & $\begin{array}{l}\text { The findings show that Indian companies have not } \\
\text { yet developed a universal approach to } \\
\text { environmental accounting and reporting as there is } \\
\text { a lack of environment reporting guidelines. }\end{array}$ \\
\hline 3.3 & 2012 & $\begin{array}{l}\text { Arora \& } \\
\text { Kapoor }\end{array}$ & $\begin{array}{l}\text { To study a sample of } 210 \text { listed companies } \\
\text { out of } 1591 \text {, provided by CMIE in the } \\
\text { category of manufacturing companies in } \\
2005 \text { to look into the practices followed by } \\
\text { Indian Companies. }\end{array}$ & $\begin{array}{l}\text { The findings revealed that environmental } \\
\text { disclosure information in annual reports has not } \\
\text { kept pace with the legislative reform; there has } \\
\text { been a significant increase of these disclosures. }\end{array}$ \\
\hline 3.4 & 2013 & Kundra & $\begin{array}{l}\text { To discuss the environmental reporting } \\
\text { practices of Indian companies by analysing } \\
\text { the annual reports and websites of } \\
\text { companies. }\end{array}$ & $\begin{array}{l}\text { The findings show that green initiatives are } \\
\text { industry specific to some extent. The findings also } \\
\text { reveal that Wipro and Infosys top the list for } \\
\text { disclosing environmental information in India. }\end{array}$ \\
\hline 4 & \multicolumn{4}{|c|}{ Relevance of firm-specific factors in the level of Environmental Disclosure by Indian Companies } \\
\hline 4.1 & 2009 & $\begin{array}{l}\text { Singh } \quad \& \\
\text { Joshi }\end{array}$ & $\begin{array}{l}\text { To study the environment management and } \\
\text { disclosure practices of Indian companies. }\end{array}$ & $\begin{array}{l}\text { The findings revealed environmental disclosure } \\
\text { practices by companies are of casual nature. } \\
\text { Positive relationship between profitability, size of } \\
\text { company and environmental disclosure. }\end{array}$ \\
\hline 4.2 & 2010 & $\begin{array}{l}\text { Mukherjee } \\
\text { et al }\end{array}$ & $\begin{array}{l}\text { To identify the firm-specific characteristics } \\
\text { that influences the environmental disclosures } \\
\text { of Indian companies. }\end{array}$ & $\begin{array}{l}\text { Effective tax rate, liquidity and leverage are the } \\
\text { variables which influences environmental } \\
\text { disclosures by Indian companies. }\end{array}$ \\
\hline 4.3 & 2011 & Joshi et al & $\begin{array}{l}\text { To examine the factors influencing the level } \\
\text { of environmental disclosure information in } \\
\text { Indian companies. }\end{array}$ & $\begin{array}{l}\text { Large sized firms which are heavily polluted tend } \\
\text { to disclose higher level of information. } \\
\text { Profitability and financial leverage have no impact } \\
\text { on the disclosure level. }\end{array}$ \\
\hline
\end{tabular}


reporting along with the annual reports and Sustainability Reporting which include the economic, environmental and social issues. The findings also show that Indian companies have not yet developed a universal approach to environmental accounting and reporting as there is a lack of environment reporting guidelines.

Arora and Kapoor (2012) use content analysis on a sample of 210 listed manufacturing companies to comment on the environmental disclosure practices of Indian companies. They find that out of 210 companies, 106 have stated something about their environmental aspects and shown some concern while the remaining 104 companies do not state even a sentence regarding their environmental activities. They also find that the environmental disclosure information in annual reports has not kept pace with the legislative reform; though there has been a significant increase in these disclosures. Kundra (2013) discusses the environmental reporting practices and green initiatives of Nifty companies by analysing the annual reports for the year 2011-2012 and finds that green initiatives are industry specific to some extent.

Some of the studies in literature have examined the relevance of firm-specific factors in the level of environmental disclosure by Indian companies [Singh \& Joshi (2009), Mukherjee et al. (2010); Joshi et al (2011)]. Mukherjee et al. (2010) conduct a multi-regression analysis on a sample of ten environmentally sensitive industries in India to know the relationship between firm characteristics and environmental disclosure. The results show that effective tax rate, liquidity and leverage are the variables that influence environmental disclosure. Joshi et al. (2011) examine the annual reports of 45 industrial listed companies. Using multi-regression analysis, they find a positive association between log of total assets and industry type with the environmental disclosure index. However, profitability and financial leverage have no impact on the disclosure index. They use environmental disclosure index to measure the amount of disclosure for environmental information in Indian companies. The table summarizes the studies reviewed by the document on Environmental Disclosure Practices of Companies (Table 1).

Most of the studies in respect of Indian companies have been conducted before the introduction of the circular on Business Responsibility Reports (BRR) by Securities and Exchange Board of India (SEBI). SEBI, vide its circular dated 13 August 2012, has decided to make it mandatory to include the BRRs as part of the annual reports for top 100 listed entities. Our study would look at the nature and extent of environmental disclosure practices of Indian companies after the introduction of SEBI's directive. It would enable us to understand if mandatory provisions in respect of business responsibility disclosures result in an increase in the extent of environmental reporting.

\section{Environmental Reporting in India}

India has no mandatory environmental reporting provided by the government or industry bodies. Therefore, Indian companies design their own mechanism and follow certain practices for disclosure. Except for some high performing and profitable Indian companies, majority of the companies in India have not started complying with the GRI (Global Reporting Initiative) guidelines. GRI Reporting Guidelines are the international standard that requires disclosure of Environmental, Social and Governance (ESG) information. They provide guidelines to organisations on how they can disclose their sustainability performance. During the last decade, there has been a growing awareness on the disclosure of environmental performance, owing to United Nations Framework on Climate Change and Kyoto Protocol. The ecological degradation caused by economic development has raised concern about the environmental practices of business and industry. Internationally, environmental reporting is being seen as a way of increasing accountability of organisations regarding environmental issues. Chart 1 compares the number of organisations releasing Sustainability reports amongst the BRICS countries. Only 74 organisations from India have released sustainability reports which are far less as compared to its neighboring developing country China.

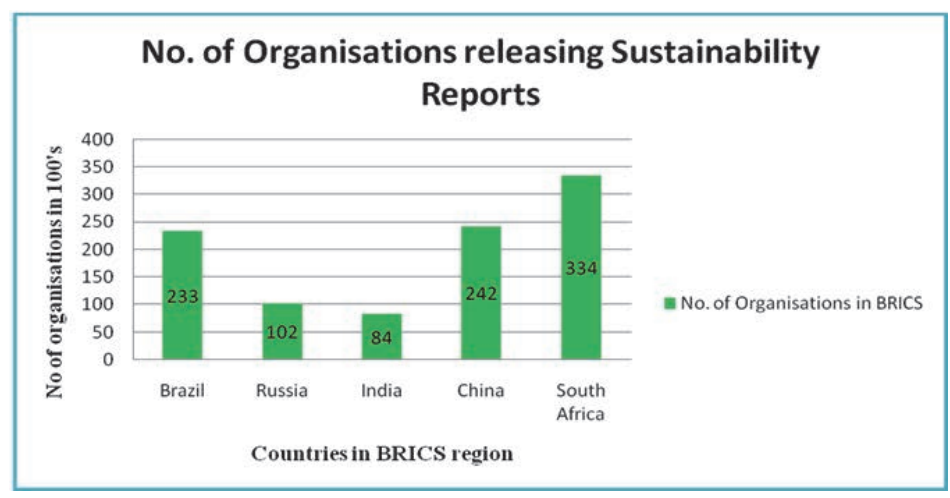

Chart 1: Number of Organisations in the BRICS region releasing Sustainability Reports (2011-2012)

Source: GRI Reporting Database

The economic reforms started by Government of India during the early 90s, have accelerated rapid economic development and the process of industrialisation. As industrialisation creates more environmental problems such as pollution and greenhouse gas (GHG) emissions, companies have started providing information about their environmental performance and policies owing to increased accountability. As noted above, there has also been a growing awareness internationally on the disclosure of environmental performance, particularly from those firms that have a direct and substantial influence on the environment like manufacturing, power generation, and mining. 
In India, provisions have been incorporated under various legislations and laws mandating business organisations to report on environmental matters. Some of the important provisions have been given below.

- The Companies Act, 1956, governs the overall regulation of companies in India and includes sections on disclosure. Section 217 of the Act stipulates that the Board of Directors Report (Attached to every balance sheet tabled at a company annual general meeting) shall contain information on conservation of energy such as energy conservation measures and additional investments and proposals for reduction of the consumption of energy.

- The Water (Prevention and Control of Pollution) Act 1974, the Air (Prevention and Control of Pollution) Act 1981, and the Environment Protection Act 1981 are three important Acts made by Government of India to translate the constitutional mandate into action.

- The National Conservation Strategy on Environment \& Development of 1992, the Policy Statement for Abatement of Pollution of 1992, and the National Forest Policy of 1988 perhaps are the three documents related to the policy framework concerning environmental protection in Indian context.

- The Ministry of Environment and Forests is the apex body in India which is responsible for planning, promotion, coordination and overseeing of Environmental programmes in India.

- National Environmental Policy (NEP) 2006, approved by the Ministry of Environment and Forest recommends the use of "standardised environmental accounting practices and norms" in preparation of statutory financial statements for large industrial enterprises.

- In 2008, The Institute of Chartered Accountants of India (ICAI) has set up the ICAI -Accounting Research Foundation (ICAI-ARF), which has undertaken a special project to suggest a suitable framework for sustainability reporting for Indian companies. It is compulsory for the companies to report on social, environmental and economic initiatives.

- In 2011, The launch of the National Voluntary Guidelines on Social, Environmental and Economic Responsibilities launched by the Ministry of Corporate Affairs, Government of India. These guidelines can be adopted voluntarily by companies of any size, operation and sector for the interests of various stakeholders.

In 2012, SEBI has made it mandatory for top 100 listed entities based on market capitalisation at BSE and NSE as on 31 March 2012 to include Business Responsibility Reports as part of their annual reports from the financial year ending on or after 31 December 2012.

\section{Data and Research Methodology}

We examine the extent of environment disclosure by Indian companies by analysing the annual reports of 30 companies listed on the BSE Sensex. The sample companies for our study comprise the top 30 Indian companies by market capitalization as listed on Bombay Stock Exchange (http://www.bseindia.com/). The following table lists the top 30 companies classified on the basis of sectors (Table2).

Table 2: List of Top 30 Indian companies classified sectorwise as per BSE on $17^{\text {th }}$ July 2014

\begin{tabular}{|c|c|c|}
\hline S.No. & Name of Companies & Sector \\
\hline 1. & Tata Consultancy Services Ltd & \multirow{4}{*}{$\begin{array}{l}\text { Information } \\
\text { Technology }\end{array}$} \\
\hline 2. & HCL Technologies & \\
\hline 3. & Infosys Ltd & \\
\hline 4. & Wipro Ltd & \\
\hline 5. & Larsen \& Tourbo & \multirow[t]{5}{*}{ Automobiles } \\
\hline 6. & Mahindra \& Mahindra & \\
\hline 7. & Maruti Suzuki & \\
\hline 8. & Tata Motors & \\
\hline 9. & Bajaj Auto & \\
\hline 10. & Axis Bank & \multirow[t]{6}{*}{ Banking } \\
\hline 11. & HDFC Bank Ltd & \\
\hline 12. & Kotak Mahindra & \\
\hline 13. & State Bank of India & \\
\hline 14. & Housing Development Finance & \\
\hline 15. & ICICI & \\
\hline 16. & Hindustan Zinc & \multirow[t]{5}{*}{ Mining/Metals } \\
\hline 17. & NMDC & \\
\hline 18. & Coal India & \\
\hline 19. & Cairn India & \\
\hline 20. & Sesa Sterlite & \\
\hline 21. & Reliance Industries & \multirow{3}{*}{$\begin{array}{c}\text { Oil } \\
\text { Exploration }\end{array}$} \\
\hline 22. & Oil and Natural Gas Corporation & \\
\hline 23. & Indian Oil & \\
\hline 24. & ITC & \multirow[t]{2}{*}{ FMCG } \\
\hline 25. & Hindustan Unilever Ltd & \\
\hline 26. & Power grid Corporation of India Ltd & \multirow[t]{2}{*}{ Power } \\
\hline 27. & NTPC & \\
\hline 28. & Sun Pharmaceutical Industries Ltd & Pharmaceutical \\
\hline 29. & Bharti Airtel Ltd & Telecom \\
\hline 30. & Ultra Tech Cement Ltd & Cement \\
\hline
\end{tabular}


Since companies with large market capitalization have a greater impact on the economy and environment, they should be more accountable for the environmental implications of their operations.

This study will contribute to the existing literature by examining the extent of environmental disclosure practices of Indian companies post the SEBI directive of mandatory inclusion of Business Responsibility Report in annual reports.

We investigate the extent of environmental reporting by Indian companies by examining the annual reports of the 30 companies for the period 2012-2013. Wilmhurst and Frost (2000, p. 16) define environmental disclosures as "those disclosures that relate to the impact company activities have on the physical or natural environment in which they operate". Fortes (2002) states that environmental reporting encompasses those information items that communicates whether natural resources have been used responsibly. This paper adopts these definitions as the basis for analysing information in annual reports to identify information relating to the environment.

Content Analysis has been used to investigate the amount of environmental disclosure in companies. Content Analysis refers to a set of procedures for collecting and organising information in a standardised format (US General Accounting Office -GAO, 1982). Content analysis is "any technique for making inferences by systematically and objectively identifying special characteristics of messages (Holsti, 1968). In other words, Content Analysis is a research technique which converts qualitative data in quantitative information for making logical conclusions. Seven major elements in written messages can be counted in content analysis- words or terms, themes, characters, paragraphs, items, concepts and semantics. (Berelson, 1952; Berg, 1983; Merton, 1968; Selltiz et al, 1959)

Various studied have been conducted on Environmental Disclosure using content analysis. Arora \& Kapoor (2012) categorized the information given in the annual report regarding environmental degradation, pollution, ecology, green technology etc. in five steps. Wiseman (1982); Freedman and Jaggi (1986) and Hughes et al (1986) also used content analysis. They collected four categories of disclosure information: economic factors, litigation, pollution abatement and other environmentally related information. Under each category, related disclosure items were also included. We adopt a methodology in line with the study of Tuwaijriet al. (2004) and Mukherjee et al (2010) for environmental disclosure measurement. We have used 'themes' in our study that relate to environmental disclosure information, as it is a more useful unit to count. A theme is a simple sentence, a string of words with a subject and a predicate. After an extensive literature review, we have identified 12 themes that, we believe, would sufficiently account for environmental disclosure information. The 12 themes have been placed under three broad categories:
Compliance with standards and procedures; efforts at resource conservation; and pollution abatement measures (Table 3). The information is collected from the annual reports of the sample companies on the basis of these 12 identified themes. If any company's annual report mentions about the reference of other reports for further environmental disclosure on their websites such as Sustainability Reports, than they were also referred for calculating the environmental score.

Table 3: List of themes identified for Environmental disclosure information

\begin{tabular}{|c|c|c|}
\hline S.No. & Theme & Indicator \\
\hline 1. & $\begin{array}{l}\text { Implementation of standards } \\
\text { such as ISO } 14000 \text { series, } \\
\text { ISO14064 series }\end{array}$ & \multirow[t]{2}{*}{$\begin{array}{l}\text { Compliance } \\
\text { with standards } \\
\text { and procedures }\end{array}$} \\
\hline 2. & Environmental Audits & \\
\hline 3. & Energy conservation efforts & \multirow{5}{*}{$\begin{array}{l}\text { Efforts at } \\
\text { resource } \\
\text { conservation }\end{array}$} \\
\hline 4. & Water conservation efforts & \\
\hline 5. & $\begin{array}{l}\text { Investment in solar } \\
\text { energy/wind energy }\end{array}$ & \\
\hline 6. & Use of renewable energy & \\
\hline 7. & Nature conservation projects & \\
\hline 8. & $\begin{array}{l}\text { Adoption of } \\
\text { Environmentally friendly } \\
\text { technology }\end{array}$ & \multirow[t]{5}{*}{$\begin{array}{l}\text { Pollution } \\
\text { abatement } \\
\text { measures }\end{array}$} \\
\hline 9. & $\begin{array}{l}\text { Reduction of GHG emissions } \\
\text { or } \mathrm{CO}_{2} \text { emissions }\end{array}$ & \\
\hline 10. & Recycling waste & \\
\hline 11. & Afforestation programmes & \\
\hline 12. & $\begin{array}{l}\text { Launch of Environment } \\
\text { friendly products }\end{array}$ & \\
\hline
\end{tabular}

If any information exists in the annual report related to the themes identified above, then its occurrence is denoted as 'yes' and is given a score of $(+1)$. If there is no information, it is denoted by 'no' and given a score of (0). As is well known in literature, quantitative disclosure is more objective and informative to stakeholders than qualitative and physical or general information. Thus we have assigned scores for quantitative, qualitative and general/physical information derived from content analysis. We have assigned a score of $(+3)$ for quantitative information, a score of $(+2)$ for qualitative information and a score of $(+1)$ for general or physical information. Final disclosure score is calculated by adding the total quality score and then dividing it with sum total of occurrence score. Table 4 explains the research methodology applied for the calculation of Environmental Disclosure Score taking ITC Ltd. as an example. 
Table 4: Environmental Score of ITC Ltd

\begin{tabular}{|c|c|c|c|c|}
\hline $\begin{array}{l}\text { Environmental } \\
\text { Themes }\end{array}$ & $\begin{array}{l}\text { Occur- } \\
\text { rence }\end{array}$ & Score & Information & $\begin{array}{l}\text { Quality } \\
\text { Score }\end{array}$ \\
\hline $\begin{array}{l}\text { Implementation of } \\
\text { standards such as } \\
\text { ISO } 14000 \text { series, } \\
\text { ISO14064 series. }\end{array}$ & Yes & 1 & General & 1 \\
\hline $\begin{array}{l}\text { Adoption of } \\
\text { Environmentally } \\
\text { friendly technology }\end{array}$ & Yes & 1 & Qualitative & 2 \\
\hline $\begin{array}{l}\text { Energy conservation } \\
\text { efforts }\end{array}$ & Yes & 1 & Quantitative & 3 \\
\hline $\begin{array}{l}\text { Reduction of } \mathrm{GHG} \\
\text { emissions or } \mathrm{CO}_{2} \\
\text { emissions }\end{array}$ & Yes & 1 & Quantitative & 3 \\
\hline Recycling waste & Yes & 1 & Quantitative & 3 \\
\hline $\begin{array}{l}\text { Afforestation } \\
\text { programmes }\end{array}$ & Yes & 1 & Quantitative & 3 \\
\hline $\begin{array}{l}\text { Water conservation } \\
\text { efforts }\end{array}$ & Yes & 1 & Quantitative & 3 \\
\hline $\begin{array}{l}\text { Investment in solar } \\
\text { energy/wind energy }\end{array}$ & Yes & 1 & Quantitative & 3 \\
\hline $\begin{array}{l}\text { Use of renewable } \\
\text { energy }\end{array}$ & Yes & 1 & General & 1 \\
\hline $\begin{array}{l}\text { Launch of } \\
\text { Environment } \\
\text { friendly products }\end{array}$ & Yes & 1 & Quantitative & 3 \\
\hline $\begin{array}{l}\text { Environmental } \\
\text { Audits }\end{array}$ & Yes & 1 & Qualitative & 2 \\
\hline $\begin{array}{l}\text { Nature conservation } \\
\text { Projects }\end{array}$ & No & $\mathbf{0}$ & No & $\mathbf{0}$ \\
\hline \multicolumn{5}{|c|}{$\begin{array}{l}\text { Environmental Disclosure Score }=\text { Quality Score } / \text { Occurrence Score } \\
\qquad=\mathbf{2 7 / 1 1}\end{array}$} \\
\hline
\end{tabular}

\section{Results and Analysis}

After applying content analysis as explained above, the following Environmental disclosure scores for the 30 companies were obtained (Table 5)

Table 5: Environmental Scores for the Selected Companies

\begin{tabular}{|c|l|c|}
\hline S.No & Indian Companies & $\begin{array}{l}\text { Environmental } \\
\text { Disclosure } \\
\text { Score }\end{array}$ \\
\hline 1. & ITC Ltd & 2.4545 \\
\hline 2. & Larsen \&Tourbo Ltd & 2.3333 \\
\hline 3. & HCL Technologies Ltd & 2.1000 \\
\hline 4. & Tata Consultancy Services Ltd & 2.0909 \\
\hline 5. & Mahindra \& Mahindra Ltd & 2.0833 \\
\hline 6. & Infosys Ltd & 2.0000 \\
\hline 7. & Reliance Industries Ltd & 1.9166 \\
\hline 8. & Oil and Natural Gas Corporation & 1.9090 \\
\hline 9. & Hindustan Zinc Ltd & 1.8750 \\
\hline
\end{tabular}

\begin{tabular}{|c|l|c|}
\hline 10. & Ultra Tech Cement Ltd & 1.8571 \\
\hline 11. & Wipro Ltd & 1.8181 \\
\hline 12. & Maruti Suzuki India Ltd & 1.7777 \\
\hline 13. & Hindustan Unilever Ltd & 1.6250 \\
\hline 14. & Tata Motors Ltd & 1.5000 \\
\hline 15. & NMDC Ltd & 1.4444 \\
\hline 16. & Sun Pharmaceuticals Ltd & 1.4285 \\
\hline 17. & $\begin{array}{l}\text { Power grid Corporation of India } \\
\text { Ltd }\end{array}$ & 1.4000 \\
\hline 18. & Bharti Airtel Ltd & 1.3750 \\
\hline 19. & Coal India Ltd & 1.3750 \\
\hline 20. & Cairn India & 1.3750 \\
\hline 21. & Sesa Sterlite Limited & 1.3333 \\
\hline 22 & NTPC Ltd & 1.3000 \\
\hline 23. & Axis Bank Ltd & 1.2500 \\
\hline 24. & Indian Oil Corporation Ltd & 1.2000 \\
\hline 25. & HDFC Bank Ltd & 1.0000 \\
\hline 26. & Kotak Mahindra Bank Ltd & 1.0000 \\
\hline 27. & Bajaj Auto Ltd & 1.0000 \\
\hline 28. & State Bank of India & 0.7500 \\
\hline 29. & $\begin{array}{l}\text { Housing Development Finance } \\
\text { Corp Ltd }\end{array}$ & 0.7500 \\
\hline 30. & ICICI & 0.6000 \\
\hline & & \\
\hline
\end{tabular}

The findings show that out of the sectors categorized in the study-Information Technology, Banking and Finance, Oil Exploration and Mining, Power, Automobiles and FMCG. Information technology and Automobile sector has the highest environmental score.

ITC Ltd, a diversified Indian conglomerate has the highest environmental score out of the 30 companies. High environmental score indicates good understanding of climate change related issues affecting the company and society. ITC has incorporated sustainable practices into its entire value chain. Another company in the FMCG sector, Hindustan Unilever has also shown responsible and sustainable growth.

TCS, Infosys and HCL Technologies, the three big IT companies of India have an environmental score of above two. IT companies have made a sincere and wholesome effort to ensure that it operations, procurement and consumption practices are environment friendly.

The Automobile sector has also performed well in our study. Larsen and Tourbo is the second top environmental scorer in the list. Mahindra \& Mahindra and Maruti Suzuki have also displayed a strong approach to information disclosure regarding environmental footprint with environmental scores of 2.083 and 1.777 respectively. The banking sector has the lowest rating due to the reason that banking sector has a lower environmental impact than other sectors of the economy. Axis bank and HDFC bank are the two banks that have undertaken initiatives to be green as compared to their competitors.

The two companies in the power sector namely NTPC and Power Grid Corporation of India Ltd are below 
average scorers in terms of environmental scores. Another sector, mining which results in high environment degradation has not disclosed sufficiently about their environmental impact of its operations. Coal India, Cairn India, Sesa Sterlite and NMDC have scores less than average environmental score (1.5). Hindustan Zinc was one such exception in this category; the company's score was 1.8571 . Oil exploration companies such as ONGC and Reliance have scores of 1.9090 and 1.9166 respectively. The leading energy majors of India have strived to position themselves as a leading organisation in sustainable management. The only company in the cement sector, Ultra Tech Cement Ltd with a score of 1.8571 displayed a proactive approach in reducing their environmental footprint as production of cement releases high amount of $\mathrm{CO} 2$. Pharmaceutical company Sun Pharmaceuticals and Telecom Company Airtel environmental score was insufficient to count them in the environment friendly companies list. The following chart (Chart 2) show average sector-wise environmental score of companies. Information Technology, Automobiles and FMCG sector are better environmental performers as compared to the other sectors.

Chart 2: Average Sector-Wise Environmental Score of Indian Companies

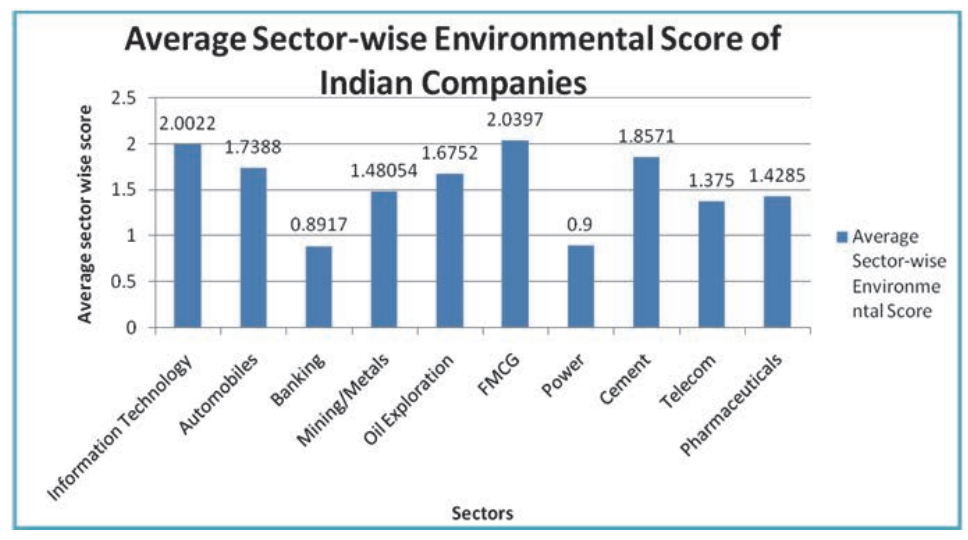

\section{Conclusion}

Climate change in India has resulted in warmer temperatures, higher frequency of heavy rainfalls, floods, droughts and changing weather patterns (World Bank, 2013). These changes, in turn, will have an impact on business, environment and community. Consequently, there is a growing group of investors that are looking beyond financial returns and considering sustainability parameters in their process of investment portfolio. International and national investors are tracking sustainability ratings of companies from the various sustainable indices such as Dow Jones Sustainability Index and FTSE4 Good Series. For tracking the environmental performance of Indian Companies, Greenex was developed to measure the performance of the top 25 green companies in terms of their GHG emissions, market capitalization and liquidity.

The increasing trend towards environmental reporting and global accounting standards has resulted in an increase in information disclosure (especially nonfinancial information) by Indian companies. The companies that do not disclose information about their entire business model may lose their competitiveness in the market. An increasing number of Indian companies are now disclosing their emission targets and climate change initiatives to the society. Our findings show that companies in the IT and automobile sector have fared quite well on the front of environmental disclosure. However, companies in sectors such as power and mining which have major environmental impacts need to disclose more on their initiatives and emissions.

Companies need to understand that investing in sustainable practices and disclosing them to the stakeholders would not only lead to a better environment but also positively impact their financial performance (WWF, 2013) due to savings of energy costs and improved image. Hence, they should be proactive in disclosing emission targets and initiatives for a better environment.

Environment protection constitutes the core of good business practices in the contemporary world. The upcoming risks of climate change require urgent and sincere efforts by companies to incorporate sustainability principles into their businesses. They should innovate to create sustainable products and services, and adopt sustainable practices such as water, energy and waste management to succeed in the marketplace. Companies that leave more environment footprint should develop a business model that lessens their environmental impact.

\section{References}

Ahmed, N.N.N. \& Sulaiman, M. (2004) "Environmental disclosures in Malaysian annual reports: a legitimacy theory perspective", International Journal of Commerce \&Management, 14(1), 44-58.

Bammi, Ruchika (2013) "An empirical analysis of Environmental \& Financial performance of BSE 100 companies", Indian Journal of Finance, 7(6).

Campbell, David (2004) "A longitudinal \& crosssectional analysis of environmental disclosure in UK companies-a research note", The British Accounting Journal, 36, 107-117.

Chateerjee, B. \& Mir, Zaman (2008) "The current status of environmental reporting by Indian Companies", .Managerial Auditing Journal, 23(6), 609629.

Fortes, H. (2002) "The need for environmental reporting by companies. Greener Management International, 40, 77-92. 
Freedman, M. \& Jaggi, B. (1986) "An analysis of the impact of corporate pollution disclosures included in Annual financial statements on investors decisions", Advances in Public Interest Accounting, 1, 193-212.

GAO (1982) "Content Analysis: A Methodology for Analyzing Written Material”, US General Accounting Office, Washington, DC.

Goyal, Neeraj (2014) "Corporate Sustainability Reporting Practices among Indian companies - Myth or reality", International Journal of Management and Social Sciences Research, 3(1), 54-60.

Gupta, Shreekant \& Goldar, Bishwanath (2003) "Do stock markets penalise environment-unfriendly Behaviour? Evidence from India", Centre for Development Economics Working Paper No 114. Retrieved from SSRN: http://ssrn.com/abstract=394621

Harte, George \& Owen, David (1991) "Environmental Disclosure in the Annual Reports of British Companies: A Research Note", Accounting, Auditing \& Accountability Journal, 4(3), 51-61.

Holsti, O. R. (1968) "Content Analysis”, in G. Lindzej \& E. Aaronson (Eds), The handbook of social psychology, Reading, MA: Addison Wesley.

Hughes, B. Susan, Anderson, Alison \& Golden, Sarah (2001) "Corporate environmental disclosures: are they useful in determining environmental performance?" .Journal of Accounting \& Public Policy, 20, 217-240.

Joshi. P, Suwaidan, M. \& Kumar, R. (2011) "Determinants of Environmental Disclosures by Indian Industrial Listed companies in their websites: Empirical Study", International Journal of Accounting and Finance,3(2), 109-130.

Kundra, Sonia (2013) "Environmental Disclosure Practices by companies in India", Pacific Business Review International, 6(2).

Malarvizhi, P. \& Yadav, S. (2008) "Corporate Environmental Reporting on the Internet - An insight into Indian practices", $11^{\text {th }}$ Annual convention of the Strategic Management Forum, IIT, Kanpur.

Mastrandonas, A. \& P. Strife (1992) "Corporate Environmental Communications", .Columbia Journal of World Business, Fall/Winter, 234-241.

Mukherjee, K., Mitali, Sen \& Pattanayak, J. K. (2010) "Firm Characteristics \& Corporate Environmental disclosure practices in India", IUP.

Patten, Dennis (2002) "The relation between environmental performance and environmental disclosure: A research note", Accounting, Organisations and Society, 27, 763-773.

Sahay, A. \& Singh, P.N. (2004) "Indian corporate environmental \& financial performance: Empirical relationship between them", Journal of Advances in Management Research, 1(3), 105-116.

Singh, Gurdip \& Joshi, Mahesh (2009) "Environment management and disclosure practices of Indian companies", International Journal of Business Research, 9(2).

Tuwaijri S. A. A., Christensen, T. E. and Hughes, K. E. (2004) "The Relations among Environmental Disclosure, Environmental Performance and Economic Performance: A Simultaneous Equation Approach", Accounting Organisation and Society, 29, 447-471.

Wilmhurst, T.D. and Frost, G.R. (2000) "Corporate environmental reporting: a test of legitimacy theory", Accounting, Auditing \& Accountability Journal, 13(1), 10-26.

Wiseman, Joanne (1982) "An evaluation of environmental disclosures made in corporate annual reports", Accounting, Organisations and Society, 7(1), 53-63.

\section{Weblinks}

- http://koffeehut.com/2009/11/20/environmentaldisclosures-in-annual-report-a-study-in-context-ofindian-manufacturing-companies-dr-suneel-arora-drgarima-kapoor/

- http://depts.washington.edu/uwmenair/chapter11.co ntent.analysis.pdf

- http://www.worldbank.org/content/dam/Worldbank/ document/Full_Report_Vol_2_Turn_Down_The_He at_\%20Climate_Extremes_Regional_Impacts_Case_ for_Resilience_Print\%20version_FINALL.pdf

- http://www.worldwildlife.org/projects/the-3-solution

- http://www.cdpla.net/es/pdf/relatorio_3percent_solut ion.pdf

- https://www.icsi.edu/Portals/0/grapes/Sustainability \%20\&\%20Reporting\%20Series-7.pdf

- http://efficientcarbon.com/blog/state-ofsustainability-reporting-in-india 